\title{
Ukrainian economic growth poles in the era of globalization
}

\author{
Leonid Rudenko, Inga Gorlenko, Eugenia Maruniak \\ Institute of Geography, National Academy of Sciences of Ukraine \\ 44 Volodymirska str., Kyiv-30, Ukraine 01030 \\ L.G.Rudenko@rambler.ru, janegeo@rambler.ru
}

\begin{abstract}
Globalization and other 21st century challenges underline the issue of finding effective management decisions and strategies in the field of spatial development, as well as their scientific basis. In Ukraine, there is a number of spatial development challenges associated with the post-Soviet transformation and integration into the world economy. The article considers the possible approaches to the promotion of spatial development policy, preconditions and barriers for its implementation. The internal and external factors of modern socio-economic development and reasons for its polarization are analysed. The trends of urban population changes in different regions are presented. An approach to the spatial development framework strengthening, vectors of growth poles indication, as well as their selection criteria are presented.
\end{abstract}

Keywords: Spatial development, polycentric development, framework, poles, centres, globalization, funding.

\section{Introduction}

During the second half of the 20th century different models of regional policy and spatial development, usually closely associated with the "centre - periphery" approach, were implemented in European countries, as well as in other regions around the world. Many experiments failed and led to intense polarization in the countries' socio-economic landscape, discrediting some concepts. First of all, it is the concept of the growth polarity (Perroux1950, Hansen N. M. 1967, Hermansen T.1972, Parr J. 1973) which justifies funding of a limited number of centres to activate and enhance the level of socioeconomic development of the region or the country as a whole. Despite some successful applications and rationality of certain provisions (see Higgins B. 1972, Newman M. 1972, Parr J. 1979), this concept was forgotten and excluded from the regional planning practice. However, the fundamental need for spatial structuring, choosing and stimulating the most promising areas could not lose its significance.

Further developments based on better understanding of diversity and hierarchical nature of central and rural areas, emphasis on connectivity and reduction in gradients, as well as the importance of territorial unity led to shifting to the idea of polycentric development, relevant today in the EU countries. "The EU Territorial Agenda to year 2020", designed to ensure the sustainable territorial development of Europe, is one of the main documents reflecting its essence.

Following the end of Soviet period in its history, Ukraine is still in need of serious reforms in the field of spatial development (Rudenko, Gorlenko 1998), in fact conforming to the European 
polycentric approach. In this case it means the improvement of the population socio-economic life's spatial framework, establishment and strengthening of centres of different scale and functions, as well as a balanced interregional socio-economic space. Primarily, this will promote the levelling off in economic landscape, development of small and medium-sized cities as potential centres of socio-economic activity and "rise " of rural areas due to population economic activity and rise in its employment.

According to the territorial planning scheme, developed in Ukraine in the seventies of the XX century, the pole and growth axes are the key elements of the spatial development framework which undoubtedly still remains the basis of the national socio-economic space and prerequisite for the socio-economic landscape formation in regions. Growth poles serve as elements of the territorial economic structure (production) and population distribution system. The essence of this concept and its main features was briefly described by the authors in the book "Problems of complex spatial development" (Rudenko, Gorlenko, Balabanov 1994) and some other publications (Rudenko, Gorlenko et al. 1994, 1998, Rudenko, Friedlein 2002), where it is noted that by the nature and extent of internal ties and by the level of relationships between their components (links) they represent social territorial complexes, united by more or less close industrial and infrastructure-territorial relations.

In the present situation by the growth poles (centres) we understand the territories which concentrate socially significant features and competitive advantages, the use of which gives or may give tangible effect for different types and levels regions (places) socio-economic development.

On the plane of spatial planning this concept is reflected by nodal areas and agglomerations with areas of their spatial influence. Obviously, first of all we mean cities, urban areas, as well as elements of the spatial structure defined by functional and institutional relations and features. Depending on the degree of growth potential realization, competitive advantages and level to which structure and functions activity are formed growth poles can be divided into 2 groups: the real and potentially predictable. Unfortunately, in Ukraine, the first group prevails over the second. Change in this imbalance will, in our opinion, will lead to spatial framework improvement and rise in competitiveness of the economy at the national and regional levels.

It is obvious that identification of promising growth poles in the regions and provision for their financial support is a strategically important inter-disciplinary issue. With complex processes of globalization and prolonged financial crisis in the background its solution requires combined efforts of scientists, politicians and managers seeking the improvement and effective implementation of economic growth advanced innovation strategy throughout entire country to provide for its key priorities.

This particularly applies to the rise in Ukraine's geopolitical status and competitiveness of its economy; development of powerful intellectual, industrial, financial and informational capacity, improvement of population quality of life and its gene pool, ensuring the economic, political and environmental security of the country as a whole.

\section{Ukrainian legislation for regional/spatial development}

Legislative level is also important. The development in due course and adoption of the Law "On General planning scheme in the Ukraine" (2001) was an innovative step which ensured establishment of an integrated planning system, substantive compliance with European imperatives. Today the document needs to be reviewed and updated, including the provisions of "EU Territorial Agenda to 
the year 2020". Another planning flaw in Ukraine is poor implementation of the "General Scheme" at the local level, as well as a weak relationship between the various types of planning - both territorial and socio-economic. As a result, numerous legislative instruments adopted as strategic for Ukraine economic and social development do not have a rigid spatial attachment, and therefore do not fully achieve the stated objectives. Among such documents could be mentioned the President of Ukraine Decree "On the strategy of economic and social development Towards European Integration for 20042015", National Development Strategy "Ukraine -2015", the Resolution of the Cabinet of Ministers Resolution "On the adoption of the State Strategy for Regional Development for the period to 2015". They outline the milestones of the advanced development of the growth poles with emphasis on innovation, new technologies, and their increased financing. For example, in the National Development Strategy "Ukraine-2015" the main areas of country's dynamic economic growth include: advanced development of high-tech sectors and sectors which enhance the "quality" of human potential development, including its intellectual component; improving the institutional environment and infrastructure for its provision; achieving a high level of economic stability, improving the imports structure, expanding import of "advanced hi-tech goods and services" and a sharp reduction in the import of products which Ukraine produced earlier and can produce now providing the domestic market, regulation of migration flows directed at reduction in quality scientific personnel leaving the country; investment regime "providing for capital inflows into more promising and strategically beneficial economic activities", etc. As we can see, the solution of these strategically important tasks for Ukraine is possible only if it is based on polycentric system of implemented "growth centres and growth poles". Unfortunately, not enough attention in these documents is paid to the mechanisms of their implementation.

\section{Globalization impact and its side backs.}

Globalization, which causes increase in interdependence among countries, interpenetration of national economies and weakening of national economic sovereignty and decline in competitiveness of individual countries, is an important factor affecting the global community, political and geo-economic situation.

Globalization's impact on development of national economies has an ambiguous character. On the one hand, this process increases the number of developed countries, strengthens their innovation and investment activity, raises their geopolitical status, financial and economic potential, and also forms the world financial and information markets, spreads scientific and technical achievements in foreign direct and portfolio investment growth in less developed countries, building new forms of innovation and investment activities - flows of technologies accompanied by documentation, etc. On the other hand, the negative aspects of globalization impacts should also be pointed out. They are clearly visible in an excessive concentration of ownership, especially of the intellectual and natural raw materials, in the most developed countries in the global financial crises; in unjustified by objective reasons sharp decline in the role some countries play in the global reproductive processes. Under the impact of globalization processes a number of challenges arise for the "third world" territorial capital utilization - depending on the economic system type, position in the geopolitical space, etc.

These problems, ambiguous influence and globalization challenges have been thoroughly studied by many authors (e.g. Kenichi 1995, Amin 2002, Sokolenko 2002, Belarus 2003, Zhalilo 2003, Brzezinski 2004). Y. Zhalilo notes globalization (Zhalilo 2003) “... provides new potential for 
building an innovative model of national economy development and limits the state's ability to use them." The fact that globalization "stimulates contradictory processes leading to traditional state sovereignty erosion, threatening the loss of national control over the key economic and social values", was emphasized by Brzezinski (Brzezinski 2004). And in this context Havrilyuk notes that in the conditions of growing globalization economic sovereignty of the state "is based on progressive - innovative country's development by competitive economy" (Havrilyuk 2011).

For Ukraine, the impact of globalization is present (Maruniak 2007):

- In economic lag, particularly in innovative national and regional level;

- In an unfavourable nature of migration processes;

- In rural areas decline;

- In transformation of urban and rural landscape shapes;

- In environmental issues and growing conflict in land use;

- In regional disparities, space fragmentation and polarization.

\section{Internal problems and urban space transformations}

Besides, there is a number of internal problems, which take their roots the in transformation period during the nineties. Firstly, we should mention that in the context of the actual growth poles deficit there is a sharp polarization in spatial development, concentration of human and financial resources, various infrastructure preferences in a few cities (mainly regional centres). The capital of Ukraine, Kiev, accounts for about $20 \%^{1}$ of GDP, $18 \%$ of export and $30 \%$ of import, $25 \%$ of FDI, $15 \%$ of economically active enterprises in Ukraine.

According to 2012 data one third of the population lives in the cities, while 10 largest cities and agglomerations account for $20 \%$ of the population, $40 \%$ of investments in fixed assets, $60 \%$ of FDI, $40 \%$ of the cost of goods sold, more than $50 \%$ - realized services. There is also degradation of industrial regions, growing problems of traditional peripheral areas (unemployment, lack of social infrastructure). Transport connectivity and accessibility, as well as the corresponding quality of infrastructure are the "weak points "of each Ukrainian region, not excluding the metropolitan. However, the most complicated problem consists in the irrational and "unfair" mechanism of budget financing allocation, lion's share of which goes for support of the depressed old industrial regions. Thus, the potential of innovative development centres - Kiev, Lviv, and Kharkiv faced with inadequate funding for research and development.

The attention should also be paid to significant transformation of the urban space in Ukraine, which should ideally act as a framework for the "central places system", the foundation of national growth.

Despite the apparent Kiev leadership, his domination in population size today is not exaggerated. In addition, according to the ratings, which in one or the other way reflect quality of urban life, Kiev does not occupy the first place. According to the "Focus" magazine ranking in $2012 \mathrm{Kiev}$ was only fifth among the best to live cities in Ukraine, trailing Ivano-Frankivsk (1) Chernivtsi (2), Donetsk (3), Lviv (4). The essence of what is happening disclosed in a concise comment "despite the financial and economic well-being, poor environment, and high crime rate, high cost of food and real estate do not allow Kiev to occupy a higher place" (Focus 2013).

\footnotetext{
${ }^{1}$ Here and then data and figures source (Statistic 2013)
} 
All large cities face similar problems. This includes problems of suburbanization. At the same time, "in the vast majority of small towns there is a prolonged socio-economic stagnation" (Liga 2013), and in some monofunctional industrial cities in Eastern Ukraine - depression, which together are responsible for decline in their population. Here we can also talk about significant regional specificities in the urban population changes (Fig. 1).
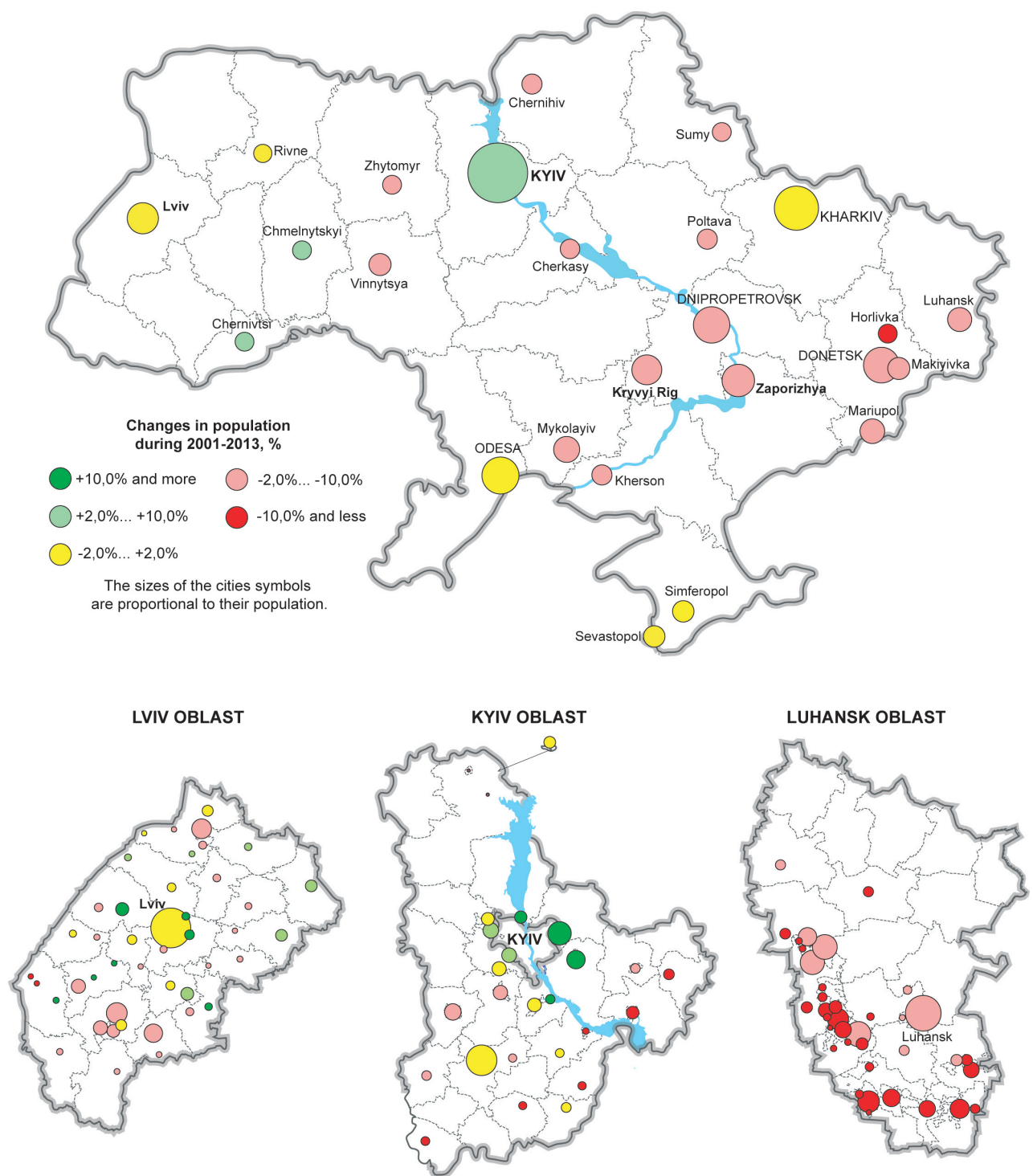

Figure 1. Urban population changes in Ukraine, 2001 - 2013

Overall results of the analysis allow us to point out sharp decline in the Ukraine Eastern regions' urban population, which is also visible both countrywide and in Luhansk (as well as Donetsk) region. Not diametrically opposed, but generally positive is the picture of changes in the Western 
regions. Certain intensification of trans-boundary cooperation can be seen in the Lviv region. In the metropolitan region there are predictably noticeable agglomeration processes.

Simultaneously, due to the modern trends (Knox, Pain 2010, Taylor et al. 2007) Ukrainian urban space meets global challenges and, according to the spatial scale, is more or less reshaped.

Summarizing the "city block" of this publication, we would like to note that despite the difficulties and conflicts of urban development, there are all prerequisites which allow to talk about polycentric settlement system "within which, under the influence of historical and economic processes six centres of inter-regional settlement systems stand out" (Rudenko, Savchuk 2013) and about its relative familiarity for the purposes of spatial development planning and integration.

\section{Methodology of spatial framework development}

We should note that, given the low scientific and technical development level, the prevalence of thirdand fourth- technological generation enterprises, low level of economy competitiveness in general, Ukraine's move to the advanced innovative development model assumes activation of the innovative component in all centres of socio-economic activities as a necessary prerequisite for their transition to growth pole. It is possible only with deep innovative changes in the area of public administration at the national, regional and local levels, with the initiation of appropriate mechanisms.

The latter, in our understanding, is a system of methods, tools, activities and influence leverage oriented at reformation of all government administration processes. Compiled together, they can be represented as follows: federally regulated balanced development of economy, social sphere and territory ecological state, legal, financial and economic mechanism.

In our opinion, in the most general form the methodological basis for spatial development framework formation should be focused on:

1. Ensuring national sovereignty, economic security, national interests and strategic priorities of innovative dynamic growth;

2. Building the information society based on the principles of sustainable balanced development;

3. Raising the country's geopolitical status and strengthening its role in the world socioeconomic processes, particularly through the implementation of competitive advantages, namely: a powerful and diverse integral development potential in most regions of the country, the presence of major scientific and technical centres and highly skilled workers in all nine economic regions of Ukraine; advantageous geopolitical and infrastructural position between Europe and Asia and between the Baltic and the Black Sea countries; predictable possibility of forming domestic or multinational companies or metropolitan areas of global importance based on some specialized agro-industrial and metallurgical complexes.

As we can see, the implementation and the rational use of these benefits is crucial for rapid growth of the existing and establishment of new centres of development in virtually all Ukraine regions.

The main vectors, when forming the poles of growth system, given the numerous, different in strength and impact direction external and internal factors, should include the following two groups: national, and particularly specified regional. The vectors of national importance are:

- The outrunning development type;

- Social orientation of the economy; 
- Innovative development that involves reform of socio-economic relations in the country, the introduction of new technologies, modernization of the main production means;

- Social, economic and ecological balance throughout all territorial organization forms centres, nodes agglomerations;

- Rational use of intellectual, mineral, land, agro-climatic, recreational and tourist resources; energy conservation;

- Ecological vector.

Regionally specified vectors include:

- The dynamic development of already existing industries and types of economic activity;

- Revival of the engineering, particularly agricultural and transport engineering;

- Active development of agriculture;

- Accelerated improvement of scientific and technical level of light and chemical industries, as well as forestry;

- Development of innovation-based recreation and tourism activities, with maximum use of its powerful potential in the Carpathians and the Black Sea region, as well as consideration of the major communication and settlement pivots.

Already at the stage of the poles of economic growth forming the possibilities of the individual type development should be defined. The criteria for their selection may be:

- Size of the area, population, number of settlements, the GDP and sales;

- The centre share and impact (GDP in the state budget, tax revenue distribution);

- Communication systems and the centre influence area;

- Participation in the territorial labour distribution;

- Functions presence and their types (industrial, scientific, technical, etc.);

- A certain type of development strategy (innovative and intensification, innovative and stabilization, innovative and environmental rehabilitation).

Specific indicators which were used in this study in the strategic analysis phase are as follows: population and its dynamics, budget income and expenses, the volume of industrial products (goods, services), capital investment, innovation activity indicators, foreign trade and foreign direct investment indicators, IT performance. Using these indicators the value of centres on the national and regional level also was calculated (for example - see Table 1).

Table 1. Some centres value on the national and regional level

\begin{tabular}{|l|c|c|c|c|c|c|c|c|}
\hline \multirow{2}{*}{$2011 / 2012$} & \multicolumn{2}{|c|}{ Population } & \multicolumn{2}{c|}{ Export } & \multicolumn{2}{c|}{ Import } & \multicolumn{2}{c|}{ FDI } \\
\cline { 2 - 9 } & $\begin{array}{c}\% \text { in } \\
\text { region }\end{array}$ & $\begin{array}{c}\% \text { in } \\
\text { Ukraine }\end{array}$ & $\begin{array}{c}\% \text { in } \\
\text { region }\end{array}$ & $\begin{array}{c}\% \text { in } \\
\text { Ukraine }\end{array}$ & $\begin{array}{c}\% \text { in } \\
\text { region }\end{array}$ & $\begin{array}{c}\% \text { in } \\
\text { Ukraine }\end{array}$ & $\begin{array}{c}\% \text { in } \\
\text { region }\end{array}$ & $\begin{array}{c}\% \text { in } \\
\text { Ukraine }\end{array}$ \\
\hline Dnipropetrovsk & 30.1 & 2.2 & 26 & 3.8 & 61 & 4.7 & 27 & 4.5 \\
\hline Kiev & 61.6 & 6.1 & 86.5 & 18.6 & 84.5 & 30.8 & 92.3 & 53.9 \\
\hline Kharkiv & 52.5 & 3.2 & 78.5 & 2.6 & 56.5 & 2.9 & 86.9 & 5 \\
\hline Odessa & 42.2 & 2.2 & 36.1 & 0.9 & 55.6 & 3.1 & 57.3 & 1.4 \\
\hline
\end{tabular}

To analyses the regional environment the indices of competitiveness (World Economic Forum methodology), Human development (UNDP methodology), Globalization (Maruniak, 2007) were 
used. The most important among them, Index of Competitiveness, includes such categories as institutions, infrastructure, macroeconomic environment, health and primary education, higher education, goods market efficiency, labour market efficiency, financial market efficiency, technological readiness, market size, business sophistication, innovations. According to an assessment for 2011-2012 years (Project of the foundation for effective governance) the leaders in competitiveness among Ukrainian regions included Kiev city and Kharkov, Odessa, Donetsk, Dnipropetrovsk, Lviv regions.

For other external evaluations attention also was paid to Global Cities and Innovation Cities Index. In 2014, Innovation Cities Index ranking includes seven Ukrainian cities - Lviv (350), Kiev (361), Odessa (397), Kharkiv (400), Dnipropetrovsk (402), Donetsk (417) and Zaporizhya (420).

Therefore, on the basis of comprehensive evaluation the existence of a small number of centres demonstrating stable growth dynamics as well as qualitative and quantitative differences was found out. Moreover, positive trends of lesser settlements growth are observed in the areas of these interregional centres. Centres such as Kyiv, Kharkiv, Dnipropetrovsk, Odessa, Lviv. Zaporizhya and Poltava are also close to this Top-5 to some degree (in the current geopolitical situation Donetsk and Lugansk cannot be taken into account).

Financial issues of growth poles strengthening

The process of centres development system formation certainly requires not only the analysis of the spatial specifics, but also attraction different types of funding. To ensure the government support for the innovative development not only in the large but also small and medium-sized cities, activation of the first and second phases of the innovation life cycle in large cities and metropolitan areas is not possible without significant financial, particularly tax potential growth in the country. Those tax levers to control the economy, gain particular importance for the federal administration system during acute shortages and weak investment activity in Ukraine. In our opinion it is appropriate to develop tax incentives in two directions. The first involves the active use of the entire system of various tax benefits that would not only be implemented through specific tax privileges and would be funnelled in the most promising growth poles and centres of social and economic activity, but would also "meet" organizational and technological specifics of economic activities located within them. The second trend provides financial support for growth poles to enhance scientific research activities related to certain phases of the innovation life cycle according to development needs. Ukraine, with its fairly conservative industry structure, obsolete technology and depreciation of fixed production assets, development of the first innovation cycle phase - scientific research and design development - and the second phase - the phase of active implementation of its results into practice are of particular importance. Active financial support of the first phase seems feasible only in the centres with strong scientific and technological potential - Kiev, Dnipropetrovsk, Kharkiv, Odessa and Lviv. Whereas the development of the second phase - implementation of the results of such developments and "specialized" innovative research projects - is more important for social and economic activity in all Ukrainian regional centres.

Taking this position, we consider it appropriate to introduce two-phase implementation of tax incentives during the heavy financial deficit in the country. At the first stage the strategic direction should be, in our opinion, specifically focused on the support for those growth poles and centres of high economic activity which develop high-yielding and competitive on international markets, as well as high-tech enterprises, techno and industrial parks, with strict control over the use of the provided benefits. This will contribute to the rapid capital turnover and will lead to cash inflows into the budgets. 


\section{Conclusions}

At the second stage the above will allow to move to the wide-scale and content rich scope of investment sources to finance small and medium-sized businesses, as well as some units of a chemical industry, agrarian complex. The above mentioned businesses and industries are engines of economic growth in Ukraine and the multiplying effect of their development will spread to other sectors of the economy. What is especially important for Ukraine that is the half-way through it will already lead to a noticeable strengthening of tax revenues, increase in taxes inflows to the state, regional and local budgets. This in turn will enhance investment and innovation processes in all regions, growth of canters, and, most importantly, this will create favourable conditions for population life improvement, the formation of large corporations and financial and industrial groups. And, as a whole - a single, inter-regional and "intercorporate" sectorial balanced socioeconomic space in Ukraine.

As for the scientific support of the discussed problem, it includes, in our opinion, three areas: the integration of all kinds of planning and improvement of spatial planning system, development of criteria and indicators for balanced spatial framework polycentric development creation; research of regional environment directed at assessment and study of differentiated financial support for urban and rural areas development opportunities.

\section{References}

Amin A., 2002. Specialities of globalization. Environment and Planning vol. 34 No. 3, pp. 385-399.

Belarus O., 2003. Economic system of globalization. Kyiv: Logos, 389 pp.

Brzezinski Z., 2004. Choice: Domination or Leadership. New York: Basic Books, 256 pp.

Focus, 2013. Living well. Focus determined the best city to live in Ukraine. http://focus.ua/society/241851/ [17 August 2012].

Hansen N. M., 1967. Development pole theory in a regional context. Kyklos, vol. 20, pp. 709-727.

Havryluk O., 2011. Globalization and Sovereignty: Economic Criteria and Means of Provision. Finance of Ukraine, no. 3, pp. 111-126.

Hermansen T., 1972. Development poles and related theories: a synoptic review. [in:] N. M. HANSEN (Ed.) Growth Centers and Regional Economic Development. New York: The Free Press, pp. 160-203.

Higgins B., 1972 Growth pole policy in Canada. [in:] N. M. HANSEN (ed.) Growth Centers in Regional Economic Development, New York: The Free Press, pp. 204-228.

Kenichi O., 1995. The End of the Nation-State: the Rise of Regional Economies. New York: Simon and Schuster Inc., 214 pp.

Knox, P., Pain K., 2010: Globalization, Neoliberalism and International Homogeneity in Architecture and Urban Development. Informationen zur Raumentwicklung 5/6, pp. 417-428.

LIGA, NEWS, 2013. Odessa, Kharkiv and Kyiv - the richest cities in Ukraine - ranking. Group of companies "Liga". http://news.liga.net [23 July 2013]

Maruniak Eu., 2007 Globalization and Its Impact on Regional Development of Ukraine. Kyiv: Referat, $224 \mathrm{pp}$. 
Newman M., 1972 Political Economy of Appalachia: A Case Study in Regional Integration. Lexington, MA: D. C. Heath.

Parr J. B., 1973. Growth poles, regional development and central place theory. Papers of the Regional Science Association, 31, pp. 174-212.

Parr J. B., 1979. Spatial structure as a factor in economic adjustment and regional policy. [in:] D. MACLENNAN and J. B. PARR (ed). Regional Policy: Past Experience and New Directions, Oxford: Martin Robertson, pp. 191-210.

Perroux F., 1950. Economic space: theory and application. Quarterly Journal of Economics, vol. 64, pp. 89-104.

Regional Policy - INTERREGIO. The EU Territorial Agenda to year 2020. European Commission http://ec.europa.eu/regional_policy/what/cohesion/index_en.cfm [19 May 2011]

Rudenko L., Friedlein G., 2002. Die Relativitat der Structur-begriffs "Peripherer Raum” in den Nachfogestaaten. Europa Regional Zeitschrift fur Lander. Leipzig: Yahrgang. No. 3. pp. 96-99.

Rudenko L., Friedlein G., Gorlenko I., Grigorowitsh M., 1998. Zentrensystemeund Raumentwich-lung inderWestlichenUkraine [in:] I.Brade (ed.) Beitrage Zur Regionalen GEOGRAPHIE. Stadtesysteme und Regional entwicklungen in Mittel- und Osteuropa - Rußland, Ukraine, Polen: Institute fur Landerkunde. Leipzig. pp. 74-131.

Rudenko L., Gorlenko I., Grigorowitsh M., Nemtchenko M., Lebed N., 1994. Zenter system als Tragerder Raumentwicklung in Mittel - und Osteuropa. Zeutreusyste-me einzelner Staateu und Regionen, pp. 78-82.

Rudenko L., Horlenko I., 1998. Sustainable Development of the Region in Ukraine: State of the Economy and Development Perspectives. Sustainable Development for Central and Eastern Spatial Development in the European Context. Springer, pp. 267-279.

Rudenko L., Horlenko I., Balabanov G., 1994. Problems of complex spatial development. Kyiv: Naukova Dumka, 296 pp.

Rudenko L., Savchuk I., 2013. Ukraine: cities space changes. Ukrainian Geographical Journal, No. 3., pp. 48-55.

Sokolenko S., 2002. Productive systems of globalization: Networks. Alliances. Partnership. Clusters: Ukrainian context. Kyiv: Logos, 645 pp.

Statistic, 2013. State Statistic Service of Ukraine, http://www.ukrstat.gov.ua [2013].

Taylor, P. J., Derudder B., Saey P., Witlox F., 2007. Cities in Globalization: Practices, Policies and Theories. London: Routledge.

Zhalilo J., 2003. State's Economic Strategy: theory, methodology, practice. Kyiv: NISS, 368 pp. 


\section{ALL VOLUMES OF EUROPA XXI}

25 (2014) : Detecting Territorial Potentials and Challenges

24 (2013) : Transport accessibility at regional scale in Europe

23 (2013) : Services of General Interest in European Union

22 (2012) : Territorial development and cohesion in a multi-scalar perspective

21 (2010) : Environmental and infrastructural networks

20 (2010) : European Union: external and internal borders, interactions and networks

19 (2009) : European urban system: metropolization and networking

18 (2008) : Territorial dilemmas of socio-economic development in Europe

17 (2008) : New functions of rural and industrial space in Central and Eastern Europe

16 (2007) : Regional development in Central Europe - cohesion or competitiveness

15 (2006) : Regional periphery in Central and Eastern Europe

14 (2006) : Core and peripheral regions in Central and Eastern Europe

13 (2005) : New spatial relations in new Europe

12 (2005) : Central and Eastern Europe: changing spatial patterns of human activity

11 (2004) : Przestrzeń Europy. Przestrzeń Unii Europejskiej

10 (2003) : Society and environment. Towns and settlement in Europe

9 (2003) : Polska i Europa: kształtowanie przestrzeni wolności

8 (2003) : European space in the face of enlargement: the West to East European Trajectory project

7 (2002) : Slovakia and Poland: urban, social and demographic questions, relations between neighbours

6 (2001) : Integracja europejska - dylematy spójności i konwergencji regionalnej

5 (2000) : Przestrzeń ekologiczna Polski. Dekolektywizacja rolnictwa i sytuacja zdrowotna w Europie Środkowej, Wschodniej i Południowo-Wschodniej

4 (2000) : Powiązania handlowe Polski z Europą. Z debaty o przyszłym kształcie zjednoczonej Europy

3 (1999) : Obszary szczególnej troski i nowych możliwości rozwoju na przykładzie Polski i Ukrainy

2 (1998) : Przestrzeń Europy Środkowej - przykłady transformacji

1 (1998) : Sieć komunikacyjna Polski w europejskich procesach integracyjnych 


\section{The role of territorial capital in development polices}

- Aleš Nováček

Historical-geographical determinants of the west-east territorial disparities in the Central European countries

- Roman Szul

Regionalism as social capital for regional development.

Competing views

- Giancarlo Cotella

Trasferring territorial governance

in the European Union: Why, what, how and through whom?

- Simona Epasto

Convergence and cohesion: the contribution made

by Poland to the debate about regional policies

of the European Union

- Márton Czirfusz

Obliterating creative capital? Urban governance

of creative industries in post-socialist Budapest

- Monika Płaziak, Tomasz Rachwał

The role of entrepreneurship in regional development strategies (based on the Polish National Strategy

of Regional Development 2010-2020)

- Leonid Rudenko, Inga Gorlenko, Eugenia Maruniak

Ukrainian economic growth poles in the era of globalization 